\title{
Article \\ Biochemical Studies of Mitochondrial Malate: Quinone Oxidoreductase from Toxoplasma gondii
}

\author{
Rajib Acharjee 1,2,3, Keith K. Talaam 1,2, Endah D. Hartuti ${ }^{1,2,4}$, Yuichi Matsuo ${ }^{5,6}$, Takaya Sakura ${ }^{5,7}$ (D), \\ Bundutidi M. Gloria 1,2,8, Shinya Hidano ${ }^{9}$, Yasutoshi Kido ${ }^{10}$, Mihoko Mori 11,12, Kazuro Shiomi ${ }^{12}$, \\ Masakazu Sekijima ${ }^{13}{ }^{(D}$, Tomoyoshi Nozaki ${ }^{14}$, Kousuke Umeda ${ }^{15,16}$, Yoshifumi Nishikawa ${ }^{16}$ (D), \\ Shinjiro Hamano ${ }^{1,2,17}$ (D) Kiyoshi Kita ${ }^{5,14,18}$ and Daniel K. Inaoka ${ }^{5,7,14, *(D)}$
}

\section{check for} updates

Citation: Acharjee, R.; Talaam, K.K.; Hartuti, E.D.; Matsuo, Y.; Sakura, T.; Gloria, B.M.; Hidano, S.; Kido, Y.;

Mori, M.; Shiomi, K.; et al.

Biochemical Studies of Mitochondrial Malate: Quinone Oxidoreductase from Toxoplasma gondii. Int. J. Mol. Sci. 2021, 22, 7830. https://doi.org/ $10.3390 /$ ijms 22157830

Academic Editor: Wieslawa Jarmuszkiewicz

Received: 22 June 2021

Accepted: 19 July 2021

Published: 22 July 2021

Publisher's Note: MDPI stays neutral with regard to jurisdictional claims in published maps and institutional affiliations.

Copyright: (c) 2021 by the authors Licensee MDPI, Basel, Switzerland. This article is an open access article distributed under the terms and conditions of the Creative Commons Attribution (CC BY) license (https:// creativecommons.org/licenses/by/ $4.0 /)$
1 Program for Nurturing Global Leaders in Tropical and Emerging Communicable Disease, Graduate School of Biomedical Sciences, Nagasaki University, Nagasaki 852-8523, Japan; rajibacharjee@cu.ac.bd (R.A.); keithtalamk@gmail.com (K.K.T.); endah.dwi08@yahoo.co.id (E.D.H.); gloriadea03@gmail.com (B.M.G.); shinjiro@nagasaki-u.ac.jp (S.H.)

2 Department of Parasitology, Institute of Tropical Medicine (NEKKEN), Nagasaki University, Nagasaki 852-8523, Japan

3 Department of Zoology, University of Chittagong, Chittagong 4331, Bangladesh

4 Laboratory for Biotechnology, Agency for the Assessment and Application of Technology, South Tangerang 15314, Indonesia

5 School of Tropical Medicine and Global Health, Nagasaki University, Nagasaki 852-8523, Japan; ymatsuo@kumamoto-u.ac.jp (Y.M.); takaya.sakura@nagasaki-u.ac.jp (T.S.); kitak@nagasaki-u.ac.jp (K.K.)

6 Graduate School of Life Science, Kumamoto University, Kumamoto 860-0862, Japan

7 Department of Molecular Infection Dynamics, Institute of Tropical Medicine (NEKKEN), Nagasaki University, Nagasaki 852-8523, Japan

8 Department of Pediatric, Kinshasa University Hospital, University of Kinshasa, Kinshasa P.O. Box 123, Congo

9 Department of Immune Regulation, The Research Center for Hepatitis and Immunology, National Center for Global Health and Medicine, Chiba 272-8516, Japan; lb-21hidano@hospk.ncgm.go.jp

10 Department of Parasitology and Research Center for Infectious Disease Sciences, Graduate School of Medicine, Osaka City University, Osaka 545-8585, Japan; kido.yasutoshi@med.osaka-cu.ac.jp

11 Biological Resource Center, NITE, Kisarazu, Chiba 292-0818, Japan; mori-mihoko@nite.go.jp

12 Graduate School of Infection Control Sciences, Kitasato University, Tokyo 108-0072, Japan; shiomi@lisci.kitasato-u.ac.jp

13 Department of Advanced Computational Drug Discovery Unit, Tokyo Institute of Technology, Yokohama 226-8501, Japan; sekijima@c.titech.ac.jp

14 Department of Biomedical Chemistry, Graduate School of Medicine, The University of Tokyo, Tokyo 113-0033, Japan; nozaki@m.u-tokyo.ac.jp

15 Pathology Division, Aquaculture Research Department, Fisheries Technology Institute, Japan Fisheries Research and Education Agency, Minamiise, 516-0193, Japan; umeda_kousuke97@fra.go.jp

16 Research Unit for Host Defense, National Research Center for Protozoan Diseases, Obihiro University of Agriculture and Veterinary Medicine, Obihiro 080-8555, Japan; nisikawa@obihiro.ac.jp

17 The Joint Usage/Research Center on Tropical Disease, Institute of Tropical Medicine (NEKKEN), Nagasaki University, Nagasaki 852-8523, Japan

18 Department of Host-Defense Biochemistry, Institute of Tropical Medicine (NEKKEN), Nagasaki University, Nagasaki 852-8523, Japan

* Correspondence: danielken@nagasaki-u.ac.jp; Tel.: +81-95-819-723 
this study, we developed a new expression system for TgMQO in FN102(DE3)TAO, a strain deficient in respiratory cytochromes and dependent on an alternative oxidase. This system allowed, for the first time, the expression and purification of a mitochondrial MQO family enzyme, which was used for steady-state kinetics and substrate specificity analyses. Ferulenol, the only known MQO inhibitor, also inhibited TgMQO at $\mathrm{IC}_{50}$ of $0.822 \mu \mathrm{M}$, and displayed different inhibition kinetics compared to Plasmodium falciparum MQO. Furthermore, our analysis indicated the presence of a third binding site for ferulenol that is distinct from the ubiquinone and malate sites.

Keywords: toxoplasmosis; electron transport chain; mitochondria; membrane protein; enzyme inhibition; ferulenol

\section{Introduction}

Toxoplasmosis is a zoonosis caused by Toxoplasma gondii, an obligate intracellular apicomplexan protozoan parasite that can infect almost all nucleated cells [1-4]. Recent estimations are that $30-50 \%$ of the global population is seropositive for T. gondii [5]. It has long been considered a mild pathogen compared to other deadly apicomplexan parasites such as Plasmodium falciparum [6], the pathogen of malaria, though in many aspects T. gondii exhibits metabolic traits similar to those of Plasmodium species, particularly with regard to the hepatic stage [7]. The capacity of $T$. gondii to adapt to different environmental parameters, such as $\mathrm{pH}[8,9]$, temperature, oxidative and chemical stresses $[8,10]$, during both sexual and asexual stages in a wide range of mammalian hosts, including humans, ranks $T$. gondii as one of the most successful parasites [11].

A correlation between the geographical variations of $T$. gondii genotypes and disease manifestation in humans has been established from population genetics and epidemiological studies [11-13]. Among three known and well-characterized lineages of T. gondii (types I, II, and III), types I and II are predominantly distributed in North America and type II in Europe [14]. The seroprevalence is high [15], perhaps due to ease of transmission of T. gondii, reaching $90 \%$ in some European and South American countries, which is skewed down to $22.5 \%$ in the United States [5]. Typically, the disease is asymptomatic in immunocompetent hosts, but provokes severe illness in immunocompromised patients such as those with acquired immunodeficiency syndrome, pregnant women, or congenitally infected individuals [16,17]; without treatment, it can lead to death [18]. To date, toxoplasmosis chemotherapy options are limited, and all drugs currently used have severe side effects, are solely active against tachyzoites, and not able to clear cystic chronic infection $[19,20]$. Furthermore, Toxovax, the only vaccine for animal toxoplasmosis, is not suitable for humans because of iatrogenic infection risks and interconversion of parasite stages [21,22]. Therefore, it is needed to develop new drugs for both tachyzoites and bradyzoites in cysts with novel mechanisms of action with fewer side effects [19]. Undoubtedly, metabolic pathways or molecular targets from the parasites that are absent or different from the corresponding host pathways are attractive drug targets [19,23].

Although glucose and glutamine are the major carbon sources, the metabolic plasticity of T. gondii supports its survival in a wide host range [24,25]. However, to support the optimal growth of $T$. gondii tachyzoites and effective pathogenesis in mammalian hosts, glucose is required and cannot be complemented by other carbon sources, such as glutamine, succinate, pyruvate, glycerol, or propionate [26]. Previous studies have revealed the presence of a functional tricarboxylic acid (TCA) cycle in tachyzoites [24,27]. Moreover, the comparative expression analysis of TCA cycle enzymes has shown similar mRNA levels between tachyzoites and early bradyzoites [27]. Collectively, these findings suggest that, to meet its energy demands, this parasite acquires adenosine triphosphate (ATP) not only by glycolysis but also by oxidative phosphorylation.

The mitochondrial electron transport chain (ETC) has been proven to be a potential target for drug development against parasites [28-31]. For example, in the blood 
stream form of Trypanosoma brucei, the protozoan parasite that causes sleeping sickness, its ETC is composed mainly of glycerol-3-phosphate dehydrogenase (G3PDH) and a cyanide-insensitive trypanosome alternative oxidase (TAO). TAO is a terminal oxidase not conserved in mammalian hosts and a validated drug target for the development of species-selective drugs [32-35]. Similar to all eukaryotes, the mitochondria of the apicomplexan parasite are involved in several essential cellular metabolic pathways and serve as important drug target organelles [23,36]. Although apicomplexan parasites possess the smallest mitochondrial genomes amongst all analyzed eukaryotes [37], their mitochondria contain almost 400 putative mitochondrial matrix proteins and several inner membrane proteins [36], such as the $b c_{1}$ complex (complex III) and dihydroorotate dehydrogenase (DHODH), which are important for growth and survival [38-40].

Similar to other apicomplexans, five types of ETC dehydrogenase are coded in the T. gondii genome: type II nicotinamide adenine dinucleotide hydrogen (NADH) dehydrogenase (TgNDH2-I and TgNDH2-II) [41], succinate dehydrogenase (TgSDH or complex II) $[27,42]$, and malate:quinone oxidoreductase (TgMQO) [43] are involved in the TCA cycle; TgG3PDH $[41,44]$ is involved in lipid metabolism and redox homeostasis [45,46]; DHODH (TgDHODH) [47] catalyzes the fourth step in pyrimidine de novo biosynthesis. All these ETC dehydrogenases transfer electrons from their individual substrates to the ubiquinone-pool (UQ-pool). The electrons from the UQ-pool are sequentially transferred to cytochrome $c$ and molecular oxygen $\left(\mathrm{O}_{2}\right)$ through reactions catalyzed by complex III and cytochrome $c$ oxidase (complex IV), respectively. During electron transport, protons are translocated from the mitochondrial matrix to the intermembrane space by complexes III and IV to maintain an electrochemical gradient that is used by ATP synthase (complex V) for ATP synthesis [40]. Inhibitors of complex III, such as atovaquone [48] and endochinlike quinolone [48], are known to inhibit the proliferation of several lifecycle stages of T. gondii [49].

In contrast to $P$. falciparum, $T$. gondii seems to have the ability to obtain pyrimidine via the salvage pathway [50] in addition to the de novo pathway. T. gondii mutants auxotrophic for uracil, a salvage pathway precursor, can be obtained by knockout of carbamoyl phosphate synthetase II (CPSII, the first step of the de novo pathway); however, they are avirulent in animal models [51]. Attempts to generate DHODH (the fourth step of the de novo pathway) null mutants have failed even in the presence of uracil, although uracil auxotrophic mutants can be obtained by gene replacement of endogenous DHODH with a catalytically deficient version [47]. Collectively, these findings suggest that, in T. gondii, CPSII and DHODH might have additional roles, other than de novo pyrimidine biosynthesis, such as in parasite virulence [51] and ETC integrity [47], respectively.

MQO is widely conserved in bacteria and in some unicellular eukaryotes; however, it is absent in mammalian hosts. MQO catalyzes the irreversible conversion of malate to oxaloacetate [52] and is a key member of the TCA cycle. MQO is catalytically equivalent to the reversible mitochondrial malate dehydrogenase (mMDH) from mammals, but it differs in localization and in its electron acceptor. MQO is localized in the mitochondrial inner membrane and is linked to the ETC by using ubiquinone as the electron acceptor. In contrast, $\mathrm{mMDH}$ is a matrix protein that uses nicotinamide adenine dinucleotide $\left(\mathrm{NAD}^{+}\right)$as the electron acceptor. In apicomplexan parasites, the role of $\mathrm{MQO}$ is not completely understood, and in addition to the TCA and ETC [43], it has been suggested that MQO provides cytosolic oxaloacetate to feed the purine salvage and pyrimidine de novo pathways in the recently identified fumarate cycle $[53,54]$. Because MQO is conserved in some organisms with incomplete TCA cycles, such as Cryptosporidium parvum, it has been speculated that, in addition to its functional role, MQO can potentially have a structural role $[55,56]$.

Nonetheless, a putative MQO (DQ457183) is conserved in the T. gondii genome, which shows high similarity to MQOs from $\varepsilon$-proteobacteria [23], and thus it belongs to MQO family group 2 [57]. Interestingly, in addition to MQO, a putative mMDH (EF683092) can be found in its genome. In general, malate oxidation by MDHs is thermodynamically unfavorable, and the reduction of oxaloacetate by NADH is preferred [58]. In the presence of MQO 
and $\mathrm{MDH}$, it has been proposed that they act in antagonistic directions [59]. However, forced oxidation of malate to oxaloacetate by MDH can be anticipated at unphysiologically high malate concentrations [60].

Ferulenol, the first inhibitor of MQO identified, inhibits the growth of P. falciparum and shows synergism in combination with atovaquone [23]. Moreover, the growth of mqo-disrupted $P$. berghei is impaired, and the parasite is unable to cause cerebral malaria in a mouse model [61], indicating that MQO plays essential roles in optimum growth and virulence. In addition, because of the trifunctional role of MQO in the ETC, TCA, and fumarate cycle, it is considered as a potent pharmacological target against P. falciparum [23].

We have previously reported the development of a recombinant $P$. falciparum $\mathrm{MQO}$ (PfMQO) expression system in a bacterial membrane [BL21(DE3)], its biochemical characterization, and the identification of inhibitors [23,62]. In this report, we describe a new expression system for recombinant TgMQO in FN102(DE3)TAO (Figure S1), and for the first time, the steady-state kinetics and substrate specificity towards electron acceptors of a purified mitochondrial MQO family enzyme.

\section{Results}

\subsection{Functional Expression and Purification of Recombinant TgMQO}

TgMQO was successfully overexpressed in the membrane fractions of BL21(DE3) and FN102(DE3)TAO. Moreover, the specific activity of TgMQO was higher in FN102(DE3)TAO $(6.4 \pm 0.6 \mu \mathrm{mol} / \mathrm{min} / \mathrm{mg})$ than in BL21(DE3) $(2.84 \pm 0.16 \mu \mathrm{mol} / \mathrm{min} / \mathrm{mg})$ membrane fractions. In addition, the specific activity of TgMQO increased to $7.5 \pm 0.2 \mu \mathrm{mol} / \mathrm{min} / \mathrm{mg}$ in the presence of ascofuranone (AF), a specific TAO inhibitor (Figure S1) $[63,64]$. The specific activity of TgMQO was high in the membrane fraction prepared using HEPES buffer, but a fast decrease was observed after solubilization, making this buffer unfit for purification. Compared to the HEPES buffer, we found that the specific activity of TgMQO prepared with MOPS buffer was lower in the membrane fraction but higher after purification and stable for several months (Table S1). Under optimized conditions, $3.7 \mathrm{mg}$ of purified TgMQO was obtained from a 3-L culture of FN102(DE3)TAO. The purification yield was 7\%, and the specific activity was $22 \mu \mathrm{mol} / \mathrm{min} / \mathrm{mg}$ protein (measured at $37^{\circ} \mathrm{C}$ ), corresponding to a 10.5-fold increase compared with the lysate (Table S1). The specific activity of MQO in the membrane fractions was about 145-fold higher in FN102(DE3)TAO/TgMQO $(2.9 \mu \mathrm{mol} / \mathrm{min} / \mathrm{mg})$ than the endogenous MQO activity $(0.02 \mu \mathrm{mol} / \mathrm{min} / \mathrm{mg})$ (Table S1). Judging from sodium dodecyl sulphate-polyacrylamide gel electrophoresis (SDS-PAGE) (Figure S2a), the purity of TgMQO was over $90 \%$, and according to the migration length, it had a molecular weight of $61 \mathrm{kDa}$ (Figure S2a,b).

Under the high resolution clear native electrophoresis (hrCNE), two bands of TgMQO were clearly visible by GelCode Blue and activity stainings (Figure 1a). The lower (247 kDa) and higher $(486 \mathrm{kDa})$ molecular weight bands (Figure 1a,b) coincide with a tetramer and a dimer of tetramer, respectively.

\subsection{Biochemical Characterization of Purified $T g M Q O$}

Purified TgMQO was used to determine the dose response, optimum temperature, and $\mathrm{pH}$ for MQO activity. Dose response assays showed a linear response of TgMQO activity from $0.025 \mu \mathrm{g} / \mathrm{mL}$ to $2.5 \mu \mathrm{g} / \mathrm{mL}$ in the assay mixture with an $R^{2}$ value of 0.9997 and minimal change in the specific activity (Figure S3). The optimum temperature for TgMQO enzyme activity was found to be $50{ }^{\circ} \mathrm{C}$ (Figure 2a), then started to decrease. However, at ambient temperatures of 25 and $30^{\circ} \mathrm{C}$, and a physiological temperature of $37^{\circ} \mathrm{C}$, the enzyme retained around $40 \%, 50 \%$, and $70 \%$ of its maximum activity at $50{ }^{\circ} \mathrm{C}$, respectively. The optimum $\mathrm{pH}$ for TgMQO was determined under physiological temperature $\left(37^{\circ} \mathrm{C}\right)$ and, as shown in Figure 2b, it displayed a bell-shaped response and an apparent optimum $\mathrm{pH}$ with Tris- $\mathrm{HCl}$ 7.0; however, no significant difference was observed within a $\mathrm{pH}$ range of 7.0 to 8.0. The concentration of TgMQO was fixed at $0.0375 \mu \mathrm{g} / \mathrm{mL}$, and for better 
comparison with PfMQO, HEPES pH 7.0 and $37^{\circ} \mathrm{C}$ were further used to determine the kinetic parameters.

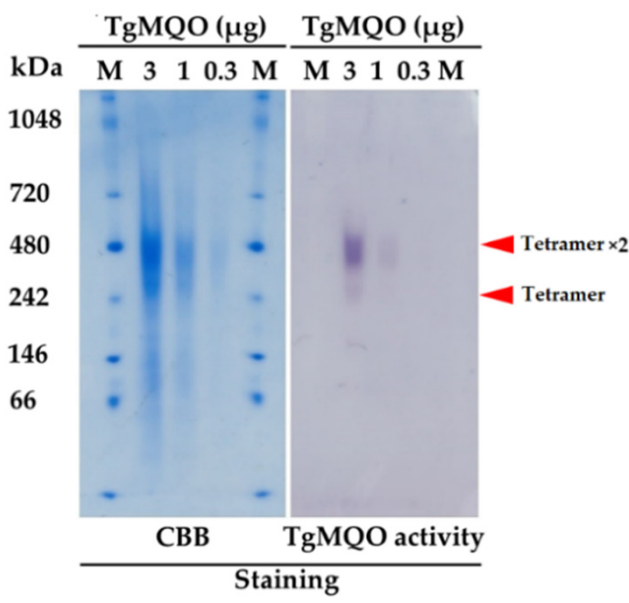

(a)

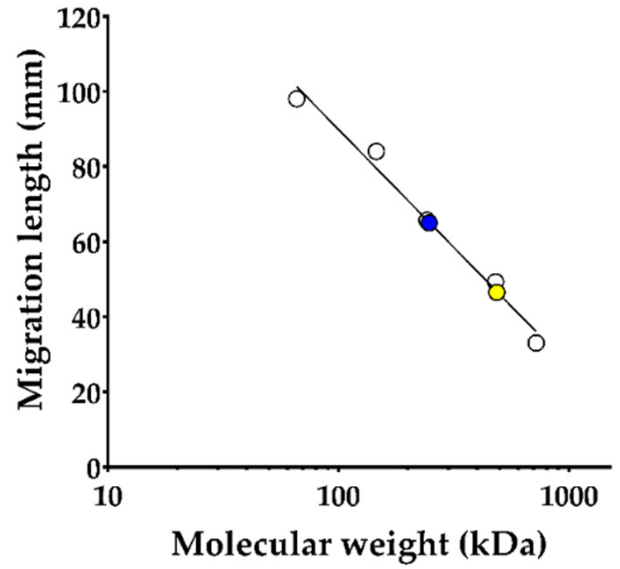

(b)

Figure 1. High resolution clear native electrophoresis (hrCNE) of TgMQO. (a) Coomassie brilliant blue (CBB) and activity staining of TgMQO. The red arrows show visible bands by both GelCode Blue and activity stainings, corresponding to tetramer and dimer of tetramer of TgMQO, respectively. $\mathrm{M}=$ NativeMark $^{\mathrm{TM}}$ protein standard, $5 \mu \mathrm{L}$. (b) Logarithmic plot (migration length vs. molecular weight) from hrCNE. The blue and yellow dots represent the molecular weights of tetramer $(247 \mathrm{kDa})$ and dimer of tetramer $(486 \mathrm{kDa})$ of TgMQO, respectively.

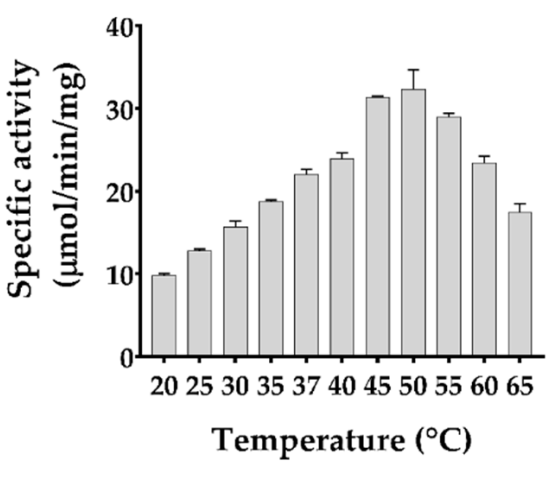

(a)

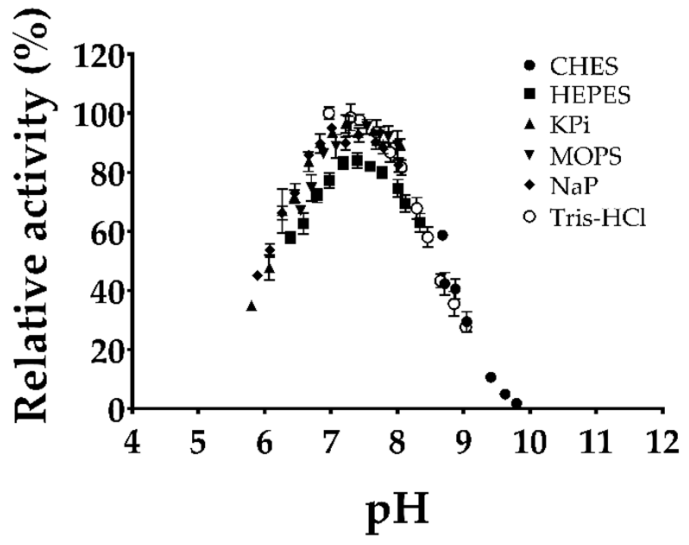

(b)

Figure 2. Optimization of purified TgMQO activity conditions. (a) TgMQO activity was assayed spectrophotometrically at varying temperatures $\left({ }^{\circ} \mathrm{C}\right)$ in triplicate. Optimum temperature was found to be higher $\left(50{ }^{\circ} \mathrm{C}\right)$ than normal physiological temperature $\left(37^{\circ} \mathrm{C}\right)$. (b) pH optimization was performed in a plate-reader under different $\mathrm{pH}$ conditions at $37^{\circ} \mathrm{C}$ and $600 \mathrm{~nm}$ in quadruplicate. Insignificant differences in TgMQO activity were observed for $\mathrm{pH}$ ranging from 7.0 to 8.0.

The kinetic parameters for different ubiquinones and malate were determined by monitoring ubiquinone reduction at $278 \mathrm{~nm}$. The affinity $\left(K_{\mathrm{m}}\right)$ values for different ubiquinones were $225,116,13.2,7.7,8.0$, and $17 \mu \mathrm{M}$, whereas $V_{\max }$ were $12.7,44.2,45.1,4.39,3.64$, and $12.1 \mu \mathrm{mol} / \mathrm{min} / \mathrm{mg}$ for UQ0, UQ1, UQ2, UQ4, UQ6, and decyl-UQ (dUQ), respectively (Table 1, Figure 3a-e). This indicates that TgMQO has a higher affinity to quinones with longer side chains, such as UQ2, UQ4, UQ6, and dUQ, compared to short ones. Interestingly, 
substrate inhibition was observed for UQ2 even at $20 \mu \mathrm{M}$ (Figure S4), but not for UQ4 and UQ6, possibly because of their low solubility in our assay conditions (Figure $3 \mathrm{a}$ ). The $K_{\mathrm{m}}$ for malate showed little variation between UQ1, UQ2, and dUQ (370, 637, and $466 \mu \mathrm{M}$, respectively) (Table 1, Figure 4a,b).

Table 1. Kinetic constants of purified TgMQO.

\begin{tabular}{|c|c|c|c|}
\hline \multicolumn{2}{|c|}{ Substrates } & \multirow{2}{*}{$\begin{array}{l}K_{\mathrm{m}} \\
(\mu \mathrm{M})\end{array}$} & \multirow{2}{*}{$\underset{(\mu \mathrm{mol} / \mathrm{min} / \mathrm{mg})}{V_{\max }}$} \\
\hline Variable & Fixed & & \\
\hline Malate & Ubiquinone-1 & $370 \pm 140$ & $6.30 \pm 0.5$ \\
\hline Malate & Ubiquinone-2 & $637 \pm 180$ & $24.6 \pm 0.8$ \\
\hline Malate & Decylubiquinone & $466 \pm 291$ & $9.55 \pm 0.6$ \\
\hline Ubiquinone-0 & Malate & $225 \pm 77$ & $12.7 \pm 3.2$ \\
\hline Ubiquinone-1 & Malate & $116 \pm 16$ & $44.2 \pm 3.8$ \\
\hline Ubiquinone-2 ${ }^{1}$ & Malate & $13.2^{1}$ & $45.1^{1}$ \\
\hline Ubiquinone-4 & Malate & $7.7 \pm 4.3$ & $4.39 \pm 0.7$ \\
\hline Ubiquinone-6 & Malate & $8.0 \pm 3.3$ & $3.64 \pm 0.4$ \\
\hline Decylubiquinone & Malate & $17 \pm 4.7$ & $12.1 \pm 1.2$ \\
\hline
\end{tabular}

Values represent the average $\pm \mathrm{SD}(n=3) .{ }^{1} \mathrm{UQ} 2$ showed substrate inhibition over $20 \mu \mathrm{M}$. So, the $K_{\mathrm{m}}$ and $V_{\max }$ calculated here were below the substrate inhibition concentration.

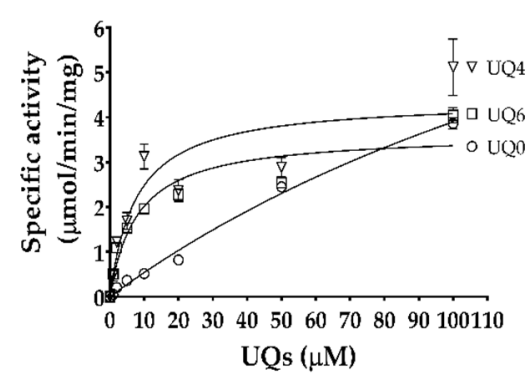

(a)

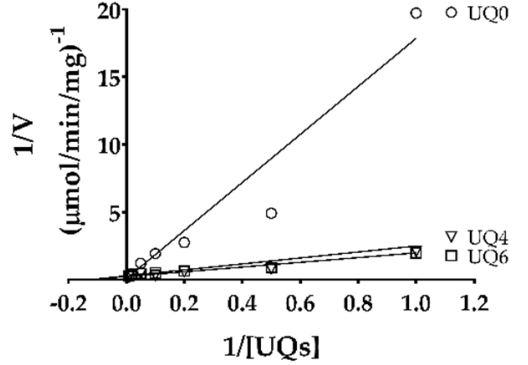

(b)

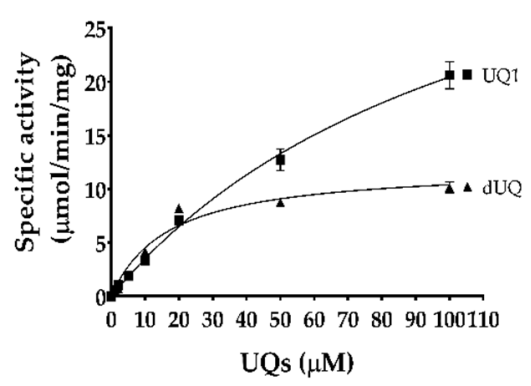

(c)

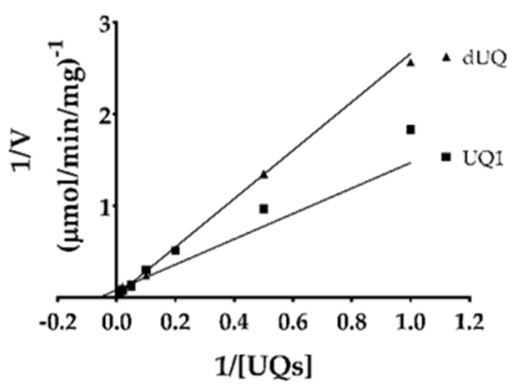

(d)

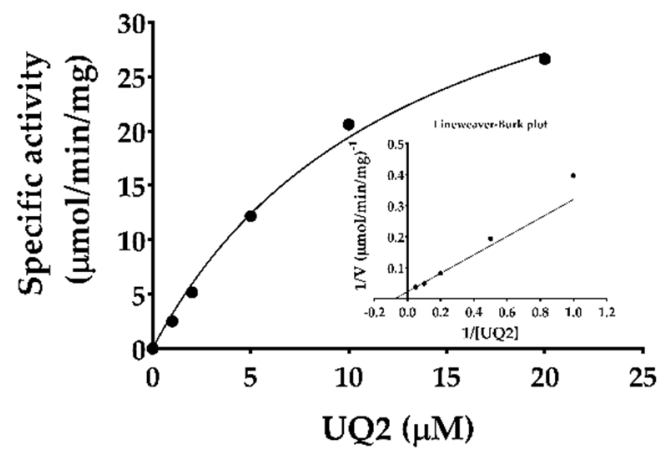

(e)

Figure 3. Kinetics of purified TgMQO with different ubiquinones. Michaelis-Menten and Lineweaver-Burk lines for UQ0, UQ4, and UQ6 (a,b); UQ1 and dUQ (c,d); and UQ2 (e). In each case, the reaction was initiated with $10 \mathrm{mM}$ malate. The kinetic constants $\left(K_{\mathrm{m}}\right.$ and $\left.V_{\max }\right)$ calculated for the ubiquinones are summarized in Table 1. Amongst the ubiquinones, UQ2 showed substrate inhibition over $20 \mu \mathrm{M}$. 


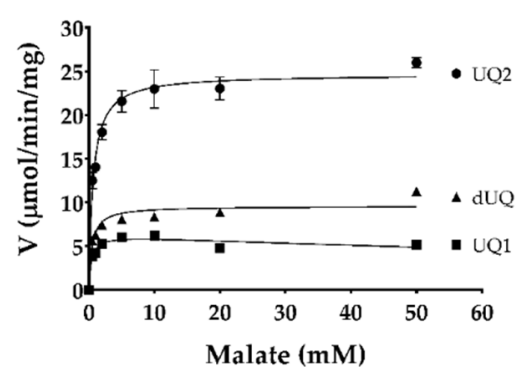

(a)

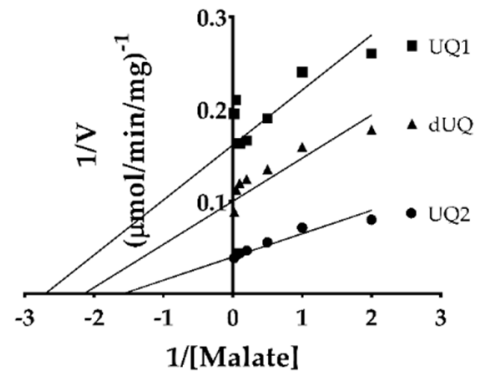

(b)

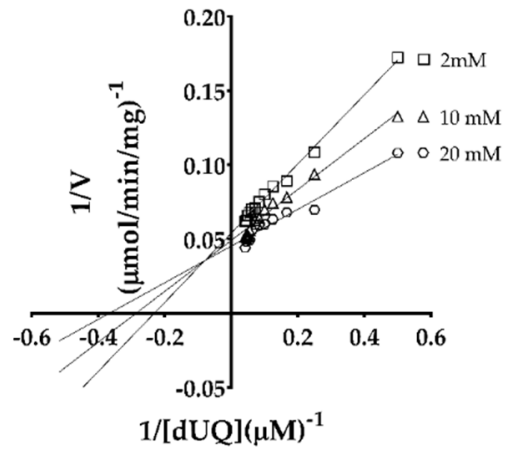

(c)

Figure 4. Determination of kinetic parameters of purified TgMQO by varying malate concentrations. (a) Michaelis-Menten curves and (b) Lineweaver-Burk plots of malate for ubiquinones (UQ1, UQ2, and dUQ). (c) The reaction mechanism catalyzed by purified TgMQO was analyzed by double reciprocal plots of TgMQO activity at varying dUQ concentrations under fixed malate concentrations of 2,10 , and $20 \mathrm{mM}$. The resulting lines intersecting above the $\mathrm{X}$-axis in the second quadrant indicate a sequential mechanism of the reaction.

The reaction mechanism of purified $\mathrm{TgMQO}$ was investigated by varying the concentration of dUQ under fixed concentrations of malate at 2, 10, and $20 \mathrm{mM}$. Our analysis showed that the lines derived from double reciprocal plots are not parallel but intersect in the second quadrant, supporting a sequential (random or ordered) reaction mechanism for TgMQO (Figure 4c).

\section{3. $I C_{50}$ and Inhibition Mechanism of Ferulenol with $\mathrm{TgMQO}$}

Ferulenol was previously identified as the first inhibitor of MQO family enzymes, displaying an $\mathrm{IC}_{50}$ of $57 \mathrm{nM}$ against PfMQO [23]. To test the effect of ferulenol on TgMQO, the $\mathrm{IC}_{50}$ was determined as $0.822 \pm 0.151 \mu \mathrm{M}$ (Figure 5a).

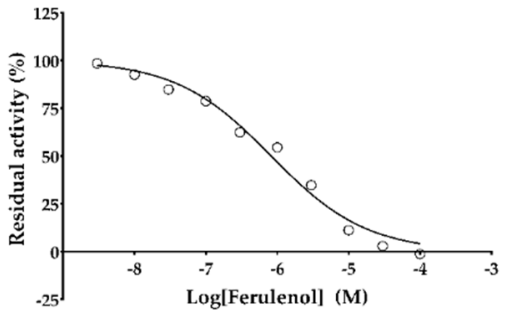

(a)

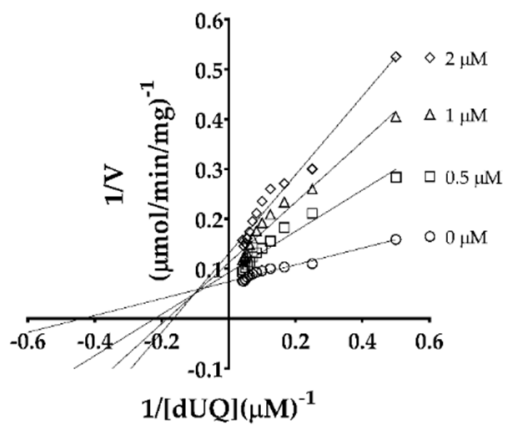

(b)

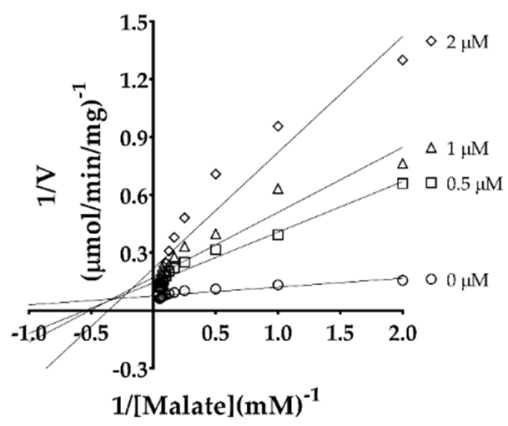

(c)

Figure 5. Inhibition of purified TgMQO activity by ferulenol. (a) TgMQO activity was assayed in the presence of serially diluted ferulenol concentrations at $278 \mathrm{~nm}$, and activity was recorded as residual activity (\%). The inhibition mechanism of ferulenol was also determined (b) vs. dUQ and (c) vs. malate. In both cases, the double reciprocal lines intersected in the second quadrant, indicating a mixed type inhibition of TgMQO activity.

Next, the inhibition mechanism of ferulenol was analyzed, and as shown in Figure 5b, double reciprocal plots obtained by varying the concentrations of dUQ yielded straight lines, which intersected in the second quadrant, suggesting a mixed type of inhibition. The same experiment performed by varying malate concentrations yielded similar results as described above, indicating a mixed type inhibition also for malate (Figure 5c). 


\section{Discussion}

We previously reported an expression system for recombinant PfMQO overexpressed in the membrane fraction of BL21(DE3) with high specific activity [23]. Since the purification of PfMQO was unsuccessful, the biochemical characterization was performed using membrane fractions in the presence of potassium cyanide $(\mathrm{KCN})$. Escherichia coli contains several terminal quinol oxidases, such as cytochrome $b o_{3}, b d$-I, and $b d$-II. Because $b d-\mathrm{I}$ and $b d$-II are $\mathrm{KCN}$-insensitive oxidases [65-67], the activity of any enzyme using a quinone/quinol-dependent assay system would be not accurate because of quinol consumption by those cytochromes (Figure $\mathrm{S1}$ ). To avoid this problem, TgMQO was expressed in FN102(DE3)TAO, because this strain lacks glutamyl-tRNA reductase (hemA), the first step of the heme biosynthesis pathway [68]. Because all terminal quinol oxidases from $E$. coli are heme dependent, the FN102(DE3) strain is unable to re-oxidize quinols and grow unless TAO, a non-heme diiron quinol oxidase, is expressed. Unlike heme-dependent terminal quinol oxidases from E. coli, TAO is specifically and potently inhibited by AF. In this study, TAO was expressed in pACYC because it is compatible with the pET system. Interestingly, the specific activity of TgMQO expressed in FN102(DE3)TAO was higher than that from the BL21(DE3) system (Figure S1). As expected, the TgMQO specific activity increased from 6.4 to $7.5 \mu \mathrm{mol} / \mathrm{min} / \mathrm{mg}$ when assayed in the absence and presence of $50 \mathrm{nM} \mathrm{AF}$, respectively (Figure S1). This clearly demonstrates that the quinone/quinol-dependent activity assayed in the conventional E. coli expression system was underestimated, and FN102(DE3)TAO is an excellent alternative expression system to study membrane-bound ETC dehydrogenases. Using this new expression system, for the first time, we purified the mitochondrial type MQO in milligram amounts with high specific activity ranging from $15-26 \mu \mathrm{mol} / \mathrm{min} / \mathrm{mg}$ depending on the lot (Table S1). Several bacterial types of MQO have been purified, such as from Geobacillus thermodenitrificans DSM $465(0.12 \mu \mathrm{mol} / \mathrm{min} / \mathrm{mg})$ [69], Acetobacter sp. SKU $14(15 \mu \mathrm{mol} / \mathrm{min} / \mathrm{mg})$ [70], Corynebacterium glutamicum $(\sim 10 \mu \mathrm{mol} / \mathrm{min} / \mathrm{mg})$ [58], Pseudomonas taetrolens $(9.3 \mu \mathrm{mol} / \mathrm{min} / \mathrm{mg})$ [71], and Bacillus sp. PS3 (24.6 $\mu \mathrm{mol} / \mathrm{min} / \mathrm{mg})$ [72]. However, no crystal structures have been reported.

Purified bacterial MQOs display variations in their oligomerization state, such as homo-dimers (Bacillus sp. PS3 and Acetobacter sp. SKU 14) and a decamer (G. thermodenitrificans DSM 465) $[69,70,72]$. Here, we provide the first evidence of the oligomeric state of mitochondrial type MQO in solution by hrCNE followed by MQO activity and CBB stainings (Figure 1a,b). As shown in Figure 1a, two bands corresponding to a tetramer $(247 \mathrm{kDa})$ and a dimer of tetramer $(486 \mathrm{kDa})$ of TgMQO were observed, the latter being more active than the tetrameric form.

In the present study, we noticed that 2,6-dichlorophenolindophenol (DCIP)-linked activity was higher than the direct detection of dUQ consumption, which was not observed for UQ2 (Figure S5). Moreover, the reduction of DCIP in the absence of quinones $(4.2 \mu \mathrm{mol} / \mathrm{min} / \mathrm{mg})$ indicates that DCIP might act directly as an electron acceptor by binding at malate and/or ubiquinone binding sites, increasing the specific activity in the presence of dUQ. The lower rate of DCIP reduction in presence of UQ2 compared to dUQ can be explained by competition for electrons between UQ2 and DCIP, which is not observed between dUQ and DCIP (Figure S5). Collectively, our data support the binding of DCIP at the ubiquinone rather than malate binding site.

Similar to PfMQO, TgMQO showed an optimum $\mathrm{pH}$ range within $\mathrm{pH} 7.0$ to 8.0, with small variations [23]. It has been demonstrated that the optimum temperature of PfMQO is $37^{\circ} \mathrm{C}$. Surprisingly, our analysis showed that TgMQO displayed an optimum temperature for its activity at $50{ }^{\circ} \mathrm{C}$ (Figure 2a). This may suggest that under physiological conditions, T. gondii mitochondria are maintained at $50{ }^{\circ} \mathrm{C}$, as recently suggested for respiratory complex enzymes (complex III, II-III, IV, and V) in mitochondria of human cells [73,74], or is the result of adaptation to mitochondrial recruitment after invasion [75-78].

The kinetic parameters of active and purified TgMQO were determined and are summarized in Table 1 . TgMQO showed a similar affinity to malate using three different quinones as electron acceptors $\left(K_{\mathrm{m}} 370,637\right.$, and $466 \mu \mathrm{M}$ for UQ1, UQ2, and dUQ, 
respectively). Those values were 10-15 times lower than the reported $K_{\mathrm{m}}$ of PfMQO (5990 $\pm 340 \mu \mathrm{M}$ using dUQ) [23]. For the electron acceptor, TgMQO showed considerably high affinity $\left(K_{\mathrm{m}}\right.$ ranging from 7 to $\left.17 \mu \mathrm{M}\right)$ to quinones with long side chains (UQ2, UQ4, UQ6, and dUQ), while for short chain quinones (UQ0 and UQ1), it displayed low affinity $\left(K_{\mathrm{m}} 116\right.$ and $\left.225 \mu \mathrm{M}\right)$. Interestingly, unlike malate, the affinity of dUQ $\left(K_{\mathrm{m}}=17 \mu \mathrm{M}\right)$ to TgMQO was approximately three times lower than the reported affinity to PfMQO $(6.2 \pm 0.65 \mu \mathrm{M})[23]$. According to our results, TgMQO employs a sequential reaction mechanism that is similar to that found for PfMQO [23], suggesting that this kind of reaction mechanism is conserved among mitochondrial-type MQOs.

Ferulenol is a sesquiterpene prenylated coumarin isolated from Ferula communis [79] that is reported to have antibacterial [80], anti-coagulant [81-83], and anti-cancer [84] activities. Several targets of ferulenol have been identified so far, such as vitamin K epoxide reductase of rat [85] and bacteria [86], complex II [79,87], PfMQO [23], Eimeria tenella DHODH [88], TAO, trypanosomal glycerol kinase [34,89,90], and human DHODH [88]. In this study, we showed that ferulenol is also an inhibitor of TgMQO; however, its $\mathrm{IC}_{50}$ was 14 times higher $(0.822 \pm 0.151 \mu \mathrm{M})$ than that of PfMQO $(0.057 \mu \mathrm{M})$ (Figure 5a) [23]. Interestingly, with TgMQO, ferulenol showed a mixed type of inhibition for malate $(\alpha=646.8)$ and dUQ $(\alpha=27.5)$ (Figure $5 b, c)$. This indicates that ferulenol may bind to TgMQO as well as TgMQO-dUQ or TgMQO-malate complexes [91], showing higher affinity to free TgMQO than to the TgMQOsubstrate complex. This finding reinforces the notion that $\mathrm{dUQ}$, malate, and ferulenol have different binding sites in TgMQO as described for PfMQO [23], but without the formation of a dead-end complex (TgMQO-dUQ-ferulenol). These patterns of inhibition by ferulenol are more consistent with a sequential ordered mechanism in which quinone binds first and then malate, similar to the mechanism described for PfMQO [23]. Nevertheless, the mixed type of inhibition of ferulenol for both substrates is a desirable feature for drug development, because it can bind to TgMQO and TgMQO-substrate complexes, hence inhibiting the enzyme function regardless of substrate concentrations in the parasite.

Finally, we identified ferulenol as the first mixed type of inhibitor of MQO, though the $\mathrm{IC}_{50}$ was in the lower $\mu \mathrm{M}$ range. As MQOs are conserved among different apicomplexan parasites and not present in their mammalian hosts, this might help to design drug candidates with novel mechanisms of action and a broad spectrum of activity with fewer side effects.

\section{Materials and Methods}

\subsection{Bacterial Strains, Plasmids, and Reagents for Recombinant TgMQO Expression}

The TgMQO gene (DQ457183), lacking the mitochondrial targeting signal (MTS; $\triangle 1-37$ residues), was codon optimized for expression in E. coli and cloned into pET151D-TOPO (Invitrogen, Carlsbad, CA, USA) to generate pET151/TgMQO, according to the manufacturer's protocol.

The gene coding for TAO was amplified from pET101/NHis6SUMO- $\triangle$ MTS-TAO [92] and cloned into pACYC-Duet (pACYC-TAO). After the sequence was confirmed, this plasmid was used to transform FN102(DE3), a heme-deficient strain unable to re-oxidize ubiquinol unless 5-aminolevulinic acid (ALA) is provided or TAO is expressed [68]. The resultant strain, FN102(DE3)TAO, was used as the expression host and transformed with pET151/TgMQO. The final strain, named FN102(DE3)TAO/TgMQO, was selected on LuriaBertani (LB) agar plates supplemented with $100 \mu \mathrm{g} / \mathrm{mL}$ carbenicillin (Wako, Kanagawa, Japan), $50 \mu \mathrm{g} / \mathrm{mL}$ kanamycin (Wako), $50 \mu \mathrm{g} / \mathrm{mL}$ chloramphenicol (TCI, Zwijndrecht, Belgium), and $50 \mu \mathrm{g} / \mathrm{mL}$ ALA.

\subsection{Overexpression of Active TgMQO in the Bacterial Membrane}

A frozen stock of FN102(DE3)TAO/TgMQO in 20\% (v/v) glycerol (Wako) was used to streak LB agar plates containing antibiotics and ALA, then kept at $37^{\circ} \mathrm{C}$ overnight. Colonies were inoculated into $150 \mathrm{~mL}$ pre-cultures of Terrific Broth (TB) medium containing $100 \mu \mathrm{g} / \mathrm{mL}$ carbenicillin, $50 \mu \mathrm{g} / \mathrm{mL}$ kanamycin, and $50 \mu \mathrm{g} / \mathrm{mL}$ chloramphenicol for $\sim 48 \mathrm{~h}$ 
(without ALA). The pre-cultures were transferred into 10 glass flasks, each containing $300 \mathrm{~mL}$ of TB medium supplemented with the above antibiotics to an initial OD600 (optical density) of 0.1 . The expression of TgMQO was induced by the addition of $100 \mu \mathrm{M}$ isopropyl $\beta$-D-thiogalactopyranoside (Sigma, Steinheim, Germany) and cultured at $30^{\circ} \mathrm{C}$ on a rotary shaker (200 rpm; Bioshaker BR-43FL; Taitec, Saitama, Japan) until the OD600 reached 4.0 to $5.0(48-72 \mathrm{~h})$. All of the following processes were performed at $4{ }^{\circ} \mathrm{C}$. The cells were harvested by centrifugation at $5000 \times g$ for $15 \mathrm{~min}$, the pellet was resuspended in lysis buffer [50 mM MOPS (Dojindo, Kumamoto, Japan) pH 8.0 and $250 \mu \mathrm{M}$ phenylmethylsulfonyl fluoride (PMSF, Wako)], and cells were lysed by a single passage through a French Press (Ohtake) at $180 \mathrm{MPa}$. Unbroken cells and debris were removed by centrifugation at $30,000 \times g$ for $30 \mathrm{~min}$ (R20A2 rotor, Hitachi, Tokyo, Japan), and the supernatant was ultracentrifuged at $200,000 \times g$ for $1 \mathrm{~h}$ (45TI rotor, Hitachi). The crude membrane pellet was homogenized in a buffer containing $50 \mathrm{mM}$ MOPS pH 8.0, $5 \mathrm{mM}$ imidazole (Wako), $150 \mathrm{mM} \mathrm{KCl}$ (Wako), and $200 \mu \mathrm{M}$ flavin adenine dinucleotide (FAD, Sigma) and then stored in $50 \%(v / v)$ glycerol (Wako) at $-30{ }^{\circ} \mathrm{C}$ until purification. The membrane fraction from FN102(DE3)TAO harboring empty pET151 was cultured and prepared in parallel for use as a control.

\subsection{Purification of $T g M Q O$ from the Membrane Fraction}

The membrane fraction at a concentration of $9.4 \mathrm{mg} / \mathrm{mL}$ was diluted (1:1 volume ratio) with dilution buffer (50 mM MOPS $\mathrm{pH}$ 8.0, $200 \mu \mathrm{M}$ FAD) and mixed with solubilizing buffer [50 mM MOPS pH 8.0, 2\% ( $w / v)$ n-octyl- $\beta$-D-glucopyranoside (OG, Dojindo), $10 \mathrm{mg} / \mathrm{mL}$ 1,2-diacyl-sn-glycero-3-phosphocholine (Sigma), $200 \mu \mathrm{M}$ FAD] at a 1:1 volume ratio, followed by gentle rotation (Rotator RT-50, Taitec) for $30 \mathrm{~min}$. The solubilized membrane was subjected to ultracentrifugation (S50A-2224 rotor, Hitachi CS150FNX) at 200,000 $\times g$ for $1 \mathrm{~h}$ to remove the insoluble proteins. The supernatant was mixed with $1.5 \mathrm{~mL}$ cOmplete ${ }^{\mathrm{TM}}$ His-Tag Purification Resin (Roche, Mannheim, Germany) pre-equilibrated with wash buffer A [50 mM MOPS pH 8.0, 0.1\% $(w / v)$ OG, $200 \mu \mathrm{M}$ FAD, $1.5 \mathrm{mM}$ imidazole] and kept rotating for $2 \mathrm{~h}$. The mixture was loaded onto a Poly-Prep ${ }^{\circledR}$ Chromatography column $(20 \mathrm{~mL}$, Bio-Rad, Hercules, CA, USA), and the unbound protein was collected as flow-through. The column was washed with 20 volumes $(30 \mathrm{~mL})$ of wash buffer A followed by $30 \mathrm{~mL}$ of wash buffer B [50 mM MOPS pH 8.0, 0.1\% ( $w / v)$ OG, 20 mM imidazole, $200 \mu \mathrm{M}$ FAD]. Finally, the recombinant TgMQO was eluted with $15 \mathrm{~mL}$ of elution buffer [ $50 \mathrm{mM}$ MOPS $\mathrm{pH}$ 8.0, $0.1 \%(w / v)$ OG, $200 \mu \mathrm{M}$ FAD, $200 \mathrm{mM}$ imidazole]. A centrifugal filter device (Amicon Ultra-15, $30 \mathrm{kDA}$ cutoff, Millipore, Tullagreen, Ireland) was used to concentrate the eluted fractions. The concentrated TgMQO was mixed with glycerol and FAD to final 50\% $(v / v)$ and $200 \mu \mathrm{M}$, respectively, and stored at $-30^{\circ} \mathrm{C}$ until use.

\subsection{Protein Quantification and Electrophoresis}

Protein concentrations were determined at $595 \mathrm{~nm}$ using a Bio-Rad Protein Assay kit with bovine serum albumin (Takara, Shiga, Japan) as the standard according to the manufacturer's protocol.

Fractions from each purification step were subjected to discontinuous SDS-PAGE [93]. The stacking and separating gels were $4 \%$ and $12 \%(w / v)$ acrylamide, respectively. Samples were mixed with SDS-PAGE loading buffer [62.5 mM Tris-HCl pH 6.8, 2.5\% $(v / v)$ sodium dodecyl sulphate (SDS, Wako), $10 \%(v / v)$ glycerol, $0.002 \%(v / v)$ bromophenol blue (Wako), and $0.71 \mathrm{M} \beta$-mercaptoethanol (Wako)] to a final concentration of $1 \mathrm{mg} / \mathrm{mL}$ (except for wash 2 and concentrated sample) and heated for $10 \mathrm{~min}$ at $95^{\circ} \mathrm{C}$. Protein preparations were loaded at $10 \mu \mathrm{g}$ per well (except for wash 2 and concentrated sample) onto the gel and run alongside broad-ranged Precision Plus Protein ${ }^{\mathrm{TM}}$ Standards (Bio-Rad). The electrophoresis was carried out at $25 \mathrm{~mA}$ for $90 \mathrm{~min}$ at room temperature, and the gel was washed three times for 5 min with purified water and stained with GelCode ${ }^{\mathrm{TM}}$ Blue Safe Protein stain (Thermo Fisher Scientific, Waltham, MA, USA) according to the provider's manual. 
hrCNE was performed by adapting the reported protocol for DHODH [88]. Briefly, purified TgMQO was diluted to $0.3,0.1$, and $0.03 \mathrm{mg} / \mathrm{mL}$ in $50 \mathrm{mM}$ MOPS $\mathrm{pH} 8.0,0.05 \%$ $(v / v)$ n-dodecyl $\beta$-D-maltoside (DDM, Sigma), $0.05 \%(v / v)$ sodium deoxycholate (DOC, Nacalai Tesque, Kyoto, Japan), 0.0001\% ( $w / v)$ ponceau S (MP Biomedicals LLC, Illkirch, France), and $5 \%(v / v)$ glycerol (final concentrations). The samples $(3,1$, and $0.3 \mu \mathrm{g} /$ lane) were loaded onto a NativePAGE ${ }^{\mathrm{TM}} 4-16 \%(w / v)$ Bis-Tris gradient gel (Invitrogen) along with NativeMark ${ }^{\mathrm{TM}}$ (Invitrogen) as a protein standard in duplicate. The gel was run at $4{ }^{\circ} \mathrm{C}$ under a constant voltage of $150 \mathrm{~V}$ for approximately $90 \mathrm{~min}$ in NativePAGE ${ }^{\mathrm{TM}} 20 \times$ running buffer (Novex, Invitrogen) according to the manufacturer's manual. The cathode buffer was also supplemented with $0.05 \%(v / v)$ DDM and $0.05 \%(v / v)$ DOC. The gel was split into two sets for GelCode ${ }^{\mathrm{TM}}$ Blue Safe Protein and MQO activity stainings. The in-gel MQO-activity staining was performed by washing three times with $5 \mathrm{mM}$ MOPS $\mathrm{pH} 8.0$ for $5 \mathrm{~min}$ each at room temperature. After washing, the gel was incubated with $1.5 \mathrm{mM}$ nitro-blue tetrazolium chloride (NBT, Wako) dissolved in $5 \mathrm{mM}$ MOPS pH 8.0 for $5 \mathrm{~min}$ at room temperature. Phenazine methyl sulfate (PMS, TCI) and malate (Wako) were added to a final concentration of $0.1 \mathrm{mg} / \mathrm{mL}$ and $10 \mathrm{mM}$, respectively, mixed quickly, kept static in the dark until the bands became visible, and subsequently washed with purified water.

\subsection{Optimization of TgMQO Assay Conditions}

The dose response range of partially purified TgMQO was assayed at $37^{\circ} \mathrm{C}$ using a UV760 (Jasco-Japan, Tokyo, Japan) at different concentrations of purified TgMQO, ranging from 0.025 to $5 \mu \mathrm{g} / \mathrm{mL}$, in $1 \mathrm{~mL}$ of the reaction mixture as previously described [23] in triplicate, with a minor change of $\mathrm{KCN}$ replaced with $50 \mathrm{nM}$ AF.

Optimization of temperature for the TgMQO assay was performed spectrophotometrically using a UV760 (Jasco-Japan) equipped with a water bath circulator (Taitec). The TgMQO activity was assayed using a $1 \mathrm{~mL}$ black quartz cuvette with $50 \mathrm{mM}$ HEPES $\mathrm{pH}$ 7.0, $120 \mu \mathrm{M}$ DCIP, $50 \mathrm{nM}$ AF, $20 \mu \mathrm{M}$ dUQ, and $1.5 \mu \mathrm{g} / \mathrm{mL}$ purified TgMQO at varying temperatures in triplicate. The reaction was started by the addition of $10 \mathrm{mM}$ malate, and the activity was calculated as described previously [23].

The optimum $\mathrm{pH}$ was determined by measuring TgMQO activity at different $\mathrm{pHs}$ using $50 \mathrm{mM}$ of sodium phosphate $(\mathrm{NaPi}, \mathrm{pH} 5.8-8.0)$, potassium phosphate $(\mathrm{KPi}, \mathrm{pH}$ 5.8-8.0), HEPES-NaOH (6.8-8.4), Tris-HCl (Wako) (pH 6.9-9.0), MOPS-NaOH (Dojindo) (pH 6.5-9.0), or CHES-NaOH (Dojindo) ( $\mathrm{pH} 8.6-10.0)$ buffers at $37^{\circ} \mathrm{C}$ with a SpectraMax ${ }^{\circledR}$ Paradigm ${ }^{\circledR}$ Multi-Mode Microplate Reader (Molecular Devices, San Jose, CA, USA), as described previously [23].

\subsection{Determination of Enzyme Kinetic Parameters and Reaction Mechanism}

Kinetic parameters of different ubiquinones (UQ0, UQ1, UQ2, UQ4, UQ6, and dUQ) and malate, and the reaction mechanism of TgMQO were determined at $37^{\circ} \mathrm{C}$ and $\mathrm{pH}$ 7.0 by the direct consumption of dUQ at $278 \mathrm{~nm}\left(\varepsilon_{278}=15 \mathrm{mM}^{-1} \cdot \mathrm{cm}^{-1}\right)$ over $5 \mathrm{~min}$ in triplicate. The concentration of TgMQO was fixed at $0.0375 \mu \mathrm{g} / \mathrm{mL}$, and $K_{\mathrm{m}}$ and $V_{\max }$ were determined by varying concentrations of different ubiquinones from 1 to $100 \mu \mathrm{M}$ at $10 \mathrm{mM}$ malate. Similarly, the $K_{\mathrm{m}}$ and $V_{\max }$ of malate were determined at varying concentrations ranging between 0.5 and $100 \mathrm{mM}$ using $20 \mu \mathrm{M}$ of different ubiquinones (UQ1, UQ2, and $\mathrm{dUQ}$ ) as electron acceptors. The data were analyzed and kinetic constants calculated using GraphPad Prism 7.0 software (San Diego, CA, USA).

For comparison with PfMQO, the reaction mechanism of TgMQO was analyzed using malate/dUQ as substrates following a previous protocol [23]. In short, TgMQO activity was assayed at varying dUQ concentrations $(2,4,6,8,10,12,14,16,18$, and $20 \mu \mathrm{M})$ under malate concentrations of 2,10 , and $20 \mathrm{mM}$, in single experiments, and the $K_{\mathrm{m}}$ of dUQ was determined at each malate concentration. 


\subsection{TgMQO Inhibition with Ferulenol}

The concentration of ferulenol (AdipoGen, Liestal, Switzerland) inhibiting $50 \%$ of the TgMQO activity $\left(\mathrm{IC}_{50}\right)$ was determined at $278 \mathrm{~nm}$ using a $1 \mathrm{~mL}$ black quartz cuvette. The reaction buffer contained $50 \mathrm{mM}$ HEPES-NaOH pH 7.0, $50 \mathrm{nM} \mathrm{AF}, 20 \mu \mathrm{M}$ dUQ, and $0.0375 \mu \mathrm{g} / \mathrm{mL}$ of $\mathrm{TgMQO}$, and enzymatic activity was measured in the presence of different concentrations of ferulenol. The reaction was initiated by the addition of $10 \mathrm{mM}$ malate. The $\mathrm{IC}_{50}$ and the $K_{\mathrm{i}}^{\mathrm{app}}$ were calculated as previously described [94].

The inhibition mechanism versus dUQ was determined using a reaction mix containing $50 \mathrm{mM}$ HEPES $\mathrm{pH} 7.0,50 \mathrm{nM}$ AF, and $0.0375 \mu \mathrm{g} / \mathrm{mL}$ TgMQO. TgMQO activity was measured at different dUQ concentrations $(2,4,6,8,10,12,14,16,18,20,22$, and $24 \mu \mathrm{M}$ ) under $0,0.5,1$, and $2 \mu \mathrm{M}$ of ferulenol. The inhibition mechanism versus malate was determined using different malate concentrations $(0.5,1,2,4,6,8,10,12,14,16,18$, and $20 \mathrm{mM}$ ) under a fixed dUQ concentration of $20 \mu \mathrm{M}$. In both cases, the activity was measured at $278 \mathrm{~nm}$ in single experiments, and the reaction started with $10 \mathrm{mM}$ of malate. The data were analyzed using GraphPad Prism 7.0 software.

Supplementary Materials: The following are available online at https://www.mdpi.com/article/10 $.3390 /$ ijms $22157830 / \mathrm{s} 1$.

Author Contributions: Conceptualization, D.K.I., K.K., Y.K., and S.H. (Shinjiro Hamano); methodology, D.K.I., Y.K.; investigation, R.A., K.K.T., K.U., Y.M., and D.K.I.; resources, E.D.H., B.M.G., K.K.T., Y.M., S.H. (Shinya Hidano), M.M., K.S., T.N., T.S., and R.A.; data curation, R.A.; writing-original draft preparation, R.A.; writing-review and editing, R.A., D.K.I., and S.H. (Shinjiro Hamano); supervision, D.K.I., S.H. (Shinjiro Hamano), and K.K.; funding acquisition, D.K.I., K.K., M.S., T.N., Y.K., and Y.N. All authors have read and agreed to the published version of the manuscript.

Funding: This work was supported in part by grants for Infectious Disease Control from the Science and Technology Research Partnership for Sustainable Development (SATREPS, no. 10000284 to K.K. and no. 14425718 to D.K.I. and T.N.); and the Japanese Initiative for Progress of Research on Infectious Diseases for Global Epidemics JP18fm0208027 and JP18fm0208020 to D.K.I. and Y.K., from the Agency for Medical Research and Development (AMED); a Grant-in-aid for Scientific Research on Priority Areas (no. 18073004 to K.K.); a Creative Scientific Research Grant (no. 18GS0314 to K.K.) from the Japan Society for the Promotion of Science; Grants-in-aid for Scientific Research (A) 20H00620 to M.S. and D.K.I.; (B) 16K19114 and 19H03436 to K.K. and D.K.I., and (C) 19K07523 to D.K.I.; a grant from The Leading Initiative for Excellent Young Researchers (LEADER) (no. 16811362 to D.K.I.) from the Japanese Ministry of Education, Science, Culture, Sports, and Technology (MEXT); Grants-in-aid for Research on Emerging and Re-emerging Infectious Diseases from the Japanese Ministry of Health and Welfare (no. 17929833 to K.K. and T.N., and no. 20314363 to D.K.I. and T.N.).

Institutional Review Board Statement: Not applicable.

Informed Consent Statement: Not applicable.

Data Availability Statement: Not applicable.

Acknowledgments: The authors thank the Mombukagakusho: MEXT Scholarship Program (No. 172597 to R.A.) and Program for Nurturing Global Leaders in Tropical and Emerging Communicable Diseases, Graduate School of Biomedical Sciences, Nagasaki University (to R.A., K.K.T., E.D.H., and B.M.G.).

Conflicts of Interest: The authors declare no conflict of interest.

\section{References}

1. Demar, M.; Ajzenberg, D.; Maubon, D.; Djossou, F.; Panchoe, D.; Punwasi, W.; Valery, N.; Peneau, C.; Daigre, J.-L.; Aznar, C.; et al. Fatal outbreak of human toxoplasmosis along the Maroni River: Epidemiological, clinical, and parasitological aspects. Clin. Infect. Dis. 2007, 45, e88-e95. [CrossRef]

2. Dubey, J.P. Toxoplasmosis of Animals and Humans, 2nd ed.; CRC Press: Boca Raton, FL, USA, 2016; pp. 1-336.

3. Galal, L.; Schares, G.; Stragier, C.; Vignoles, P.; Brouat, C.; Cuny, T.; Dubois, C.; Rohart, T.; Glodas, C.; Dardé, M.L.; et al. Diversity of Toxoplasma gondii strains shaped by commensal communities of small mammals. Int. J. Parasitol. 2019, 49, 267-275. [CrossRef] [PubMed] 
4. Hejlícek, K.; Literák, I.; Nezval, J. Toxoplasmosis in wild mammals from the Czech Republic. J. Wildl. Dis. 1997, 33, 480-485. [CrossRef] [PubMed]

5. Flegr, J.; Prandota, J.; Sovičková, M.; Israili, Z.H. Toxoplasmosis-A Global Threat. Correlation of latent toxoplasmosis with specific disease burden in a set of 88 countries. PLoS ONE 2014, 9, e90203. [CrossRef]

6. Dubremetz, J.F.; Lebrun, M. Virulence factors of Toxoplasma gondii. Microbes Infect. 2012, 14, 1403-1410. [CrossRef] [PubMed]

7. Blume, M.; Seeber, F. Metabolic interactions between Toxoplasma gondii and its host. F1000Research 2018, 7, F1000. [CrossRef]

8. Soête, M.; Camus, D.; Dubremetz, J.F. Experimental induction of bradyzoite-specific antigen expression and cyst formation by the RH strain of Toxoplasma gondii in vitro. Exp. Parasitol. 1994, 78, 361-370. [CrossRef]

9. Weilhammer, D.R.; Iavarone, A.T.; Villegas, E.N.; Brooks, G.A.; Sinai, A.P.; Sha, W.C. Host metabolism regulates growth and differentiation of Toxoplasma gondii. Int. J. Parasitol. 2012, 42, 947-959. [CrossRef]

10. Tomavo, S.; Boothroyd, J.C. Interconnection between organellar functions, development and drug resistance in the protozoan parasite. Toxoplasma gondii. Int. J. Parasitol. 1995, 25, 1293-1299. [CrossRef]

11. Boothroyd, J.C.; Grigg, M.E. Population biology of Toxoplasma gondii and its relevance to human infection: Do different strains cause different disease? Curr. Opin. Microbiol. 2002, 5, 438-442. [CrossRef]

12. Ajzenberg, D.; Yera, H.; Marty, P.; Paris, L.; Dalle, F.; Menotti, J.; Aubert, D.; Franck, J.; Bessières, M.H.; Quinio, D.; et al. Genotype of 88 Toxoplasma gondii isolates associated with toxoplasmosis in immunocompromised patients and correlation with clinical findings. J. Infect. Dis. 2009, 199, 1155-1167. [CrossRef] [PubMed]

13. Dardé, M.L.; Villena, I.; Pinon, J.M.; Beguinot, I. Severe toxoplasmosis caused by a Toxoplasma gondii strain with a new isoenzyme type acquired in French Guyana. J. Clin. Microbiol. 1998, 36, 324. [CrossRef] [PubMed]

14. Hosseini, S.A.; Amouei, A.; Sharif, M.; Sarvi, S.; Galal, L.; Javidnia, J.; Pagheh, A.S.; Gholami, S.; Mizani, A.; Daryani, A. Human toxoplasmosis: A systematic review for genetic diversity of Toxoplasma gondii in clinical samples. Epidemiol. Infect. 2018, 147, 1-9. [CrossRef] [PubMed]

15. Jones, J.L.; Kruszon-Moran, D.; Wilson, M.; McQuillan, G.; Navin, T.; McAuley, J.B. Toxoplasma gondii Infection in the United States: Seroprevalence and Risk Factors. Am. J. Epidemiol. 2001, 154, 357-365. [CrossRef] [PubMed]

16. Dupont, C.D.; Christian, D.A.; Hunter, C.A. Immune response and immunopathology during toxoplasmosis. Semin. Immunopathol. 2012, 34, 793-813. [CrossRef]

17. Ferguson, D.J.P.; Bowker, C.; Jeffery, K.J.M.; Chamberlain, P.; Squier, W. Congenital toxoplasmosis: Continued parasite proliferation in the fetal brain despite maternal immunological control in other tissues. Clin. Infect. Dis. 2013, 56, 204-208. [CrossRef]

18. Montoya, J.G.; Liesenfeld, O. Toxoplasmosis. Lancet 2004, 363, 1965-1976. [CrossRef]

19. Konstantinovic, N.; Guegan, H.; Stäjner, T.; Belaz, S.; Robert-Gangneux, F. Treatment of toxoplasmosis: Current options and future perspectives. Food Waterborne Parasitol. 2019, 15, e00036. [CrossRef]

20. Sinai, A.P.; Watts, E.A.; Dhara, A.; Murphy, R.D.; Gentry, M.S.; Patwardhan, A. Reexamining chronic Toxoplasma gondii infection: Surprising activity for a "dormant" parasite. Curr. Clin. Microbiol. Rep. 2016, 3, 175-185. [CrossRef]

21. Buxton, D.; Innes, E.A. A commercial vaccine for ovine toxoplasmosis. Parasitology 1995, 110, S11-S16. [CrossRef]

22. Lyons, R.E.; McLeod, R.; Roberts, C.W. Toxoplasma gondii tachyzoite-bradyzoite interconversion. Trends Parasitol. 2002, 18, 198-201. [CrossRef]

23. Hartuti, E.D.; Inaoka, D.K.; Komatsuya, K.; Miyazaki, Y.; Miller, R.J.; Xinying, W.; Sadikin, M.; Prabandari, E.E.; Waluyo, D.; Kuroda, M.; et al. Biochemical studies of membrane bound Plasmodium falciparum mitochondrial L-malate:quinone oxidoreductase, a potential drug target. Biochim. Biophys. Acta Bioenerg. 2018, 1859, 191-200. [CrossRef]

24. MacRae, J.I.; Sheiner, L.; Nahid, A.; Tonkin, C.; Striepen, B.; McConville, M.J. Mitochondrial metabolism of glucose and glutamine is required for intracellular growth of Toxoplasma gondii. Cell Host Microbe 2012, 12, 682-692. [CrossRef]

25. Polonais, V.; Soldati-Favre, D. Versatility in the acquisition of energy and carbon sources by the Apicomplexa. Biol. Cell 2010, 102, 435-445. [CrossRef]

26. Shukla, A.; Olszewski, K.L.; Llinás, M.; Rommereim, L.M.; Fox, B.A.; Bzik, D.J.; Xia, D.; Wastling, J.; Beiting, D.; Roos, D.S.; et al. Glycolysis is important for optimal asexual growth and formation of mature tissue cysts by Toxoplasma gondii. Int. J. Parasitol. 2018, 48, 955-968. [CrossRef] [PubMed]

27. Fleige, T.; Pfaff, N.; Gross, U.; Bohne, W. Localisation of gluconeogenesis and tricarboxylic acid (TCA)-cycle enzymes and first functional analysis of the TCA cycle in Toxoplasma gondii. Int. J. Parasitol. 2008, 38, 1121-1132. [CrossRef]

28. Hikosaka, K.; Komatsuya, K.; Suzuki, S.; Kita, K. Mitochondria of malaria parasites as a drug target. In An Overview of Tropical Diseases; IntechOpen: London, UK, 2015.

29. Kawahara, K.; Mogi, T.; Tanaka, T.Q.; Hata, M.; Miyoshi, H.; Kita, K. Mitochondrial dehydrogenases in the aerobic respiratory chain of the rodent malaria parasite Plasmodium yoelii yoelii. J. Biochem. 2009, 145, 229-237. [CrossRef] [PubMed]

30. Mather, M.W.; Henry, K.W.; Vaidya, A.B. Mitochondrial drug targets in apicomplexan parasites. Curr. Drug. Targets 2007, 8, 49-60. [CrossRef] [PubMed]

31. Mi-Ichi, F.; Miyadera, H.; Kobayashi, T.; Takamiya, S.; Waki, S.; Iwata, S.; Shibata, S.; Kita, K. Parasite mitochondria as a target of chemotherapy: Inhibitory effect of licochalcone A on the Plasmodium falciparum respiratory chain. Ann. N. Y. Acad. Sci. 2005, 1056, 46-54. [CrossRef] 
32. Fueyo González, F.J.; Ebiloma, G.U.; Izquierdo García, C.; Bruggeman, V.; Sánchez Villamañán, J.M.; Donachie, A.; Balogun, E.O.; Inaoka, D.K.; Shiba, T.; Harada, S.; et al. Conjugates of 2,4-dihydroxybenzoate and salicylhydroxamate and lipocations display potent antiparasite effects by efficiently targeting the Trypanosoma brucei and Trypanosoma congolense mitochondrion. J. Med. Chem. 2017, 60, 1509-1522. [CrossRef] [PubMed]

33. Shiba, T.; Kido, Y.; Sakamoto, K.; Inaoka, D.K.; Tsuge, C.; Tatsumi, R.; Takahashi, G.; Balogun, E.O.; Nara, T.; Aoki, T.; et al. Structure of the trypanosome cyanide-insensitive alternative oxidase. Proc. Natl. Acad. Sci. USA 2013, 110, 201218386. [CrossRef]

34. Yamasaki, S.; Shoji, M.; Kayanuma, M.; Sladek, V.; Inaoka, D.K.; Matsuo, Y.; Shiba, T.; Young, L.; Moore, A.L.; Kita, K.; et al. Weak $\mathrm{O}_{2}$ binding and strong $\mathrm{H}_{2} \mathrm{O}_{2}$ binding at the non-heme diiron center of trypanosome alternative oxidase. Biochim. Biophys. Acta Bioenerg. 2021, 1862, 148356. [CrossRef]

35. Young, L.; Rosell-Hidalgo, A.; Inaoka, D.K.; Xu, F.; Albury, M.; May, B.; Kita, K.; Moore, A.L. Kinetic and structural characterisation of the ubiquinol-binding site and oxygen reduction by the trypanosomal alternative oxidase. Biochim. Biophys. Acta Bioenerg. 2020, 1861, 148247. [CrossRef]

36. Seidi, A.; Muellner-Wong, L.S.; Rajendran, E.; Tjhin, E.T.; Dagley, L.F.; Aw, V.Y.T.; Faou, P.; Webb, A.I.; Tonkin, C.J.; van Dooren, G.G. Elucidating the mitochondrial proteome of Toxoplasma gondii reveals the presence of a divergent cytochrome $c$ oxidase. eLife 2018, 7, e38131. [CrossRef]

37. Hikosaka, K.; Kita, K.; Tanabe, K. Diversity of mitochondrial genome structure in the phylum Apicomplexa. Mol. Biochem. Parasitol. 2013, 188, 26-33. [CrossRef]

38. Doggett, J.S.; Nilsen, A.; Forquer, I.; Wegmann, K.W.; Jones-Brando, L.; Yolken, R.H.; Bordón, C.; Charman, S.A.; Katneni, K.; Schultz, T.; et al. Endochin-like quinolones are highly efficacious against acute and latent experimental toxoplasmosis. Proc. Natl. Acad. Sci. USA 2012, 109, 15936-15941. [CrossRef] [PubMed]

39. Phillips, M.A.; Gujjar, R.; Malmquist, N.A.; White, J.; El Mazouni, F.; Baldwin, J.; Rathod, P.K. Triazolopyrimidine-based dihydroorotate dehydrogenase inhibitors with potent and selective activity against the malaria parasite Plasmodium falciparum. J. Med. Chem. 2008, 51, 3649-3653. [CrossRef] [PubMed]

40. Seeber, F.; Limenitakis, J.; Soldati-Favre, D. Apicomplexan mitochondrial metabolism: A story of gains, losses and retentions. Trends Parasitol. 2008, 24, 468-478. [CrossRef]

41. Lin, S.S.; Gross, U.; Bohne, W. Two internal type II NADH dehydrogenases of Toxoplasma gondii are both required for optimal tachyzoite growth. Mol. Microbiol. 2011, 82, 209-221. [CrossRef] [PubMed]

42. Denton, H.; Roberts, C.W.; Alexander, J.; Thong, K.W.; Coombs, G.H. Enzymes of energy metabolism in the bradyzoites and tachyzoites of Toxoplasma gondii. FEMS Microbiol. Lett. 1996, 137, 103-108. [CrossRef]

43. Jacot, D.; Waller, R.F.; Soldati-Favre, D.; MacPherson, D.A.; MacRae, J.I. Apicomplexan energy metabolism: Carbon source promiscuity and the quiescence hyperbole. Trends Parasitol. 2016, 32, 56-70. [CrossRef]

44. Lin, S.S.; Gross, U.; Bohne, W. Type II NADH dehydrogenase inhibitor 1-hydroxy-2-dodecyl-4(1H)quinolone leads to collapse of mitochondrial inner-membrane potential and ATP depletion in Toxoplasma gondii. Eukaryot. Cell 2009, 8, 877-887. [CrossRef]

45. Bisanz, C.; Bastien, O.; Grando, D.; Jouhet, J.; Maréchal, E.; Cesbron-Delauw, M.F. Toxoplasma gondii acyl-lipid metabolism: De novo synthesis from apicoplast-generated fatty acids versus scavenging of host cell precursors. Biochem. J. 2006, 394 Pt 1, $197-205$. [CrossRef]

46. Shen, W.; Wei, Y.; Dauk, M.; Tan, Y.; Taylor, D.C.; Selvaraj, G.; Zou, J. Involvement of a glycerol-3-phosphate dehydrogenase in modulating the NADH/NAD+ ratio provides evidence of a mitochondrial glycerol-3-phosphate shuttle in Arabidopsis. Plant Cell 2006, 18, 422. [CrossRef]

47. Hortua Triana, M.A.; Cajiao Herrera, D.; Zimmermann, B.H.; Fox, B.A.; Bzik, D.J. Pyrimidine pathway-dependent and independent functions of the Toxoplasma gondii mitochondrial dihydroorotate dehydrogenase. Infect. Immun. 2016, 84, $2974-2981$. [CrossRef] [PubMed]

48. Alday, P.H.; Doggett, J.S. Drugs in development for toxoplasmosis: Advances, challenges, and current status. Drug Des. Devel. Ther. 2017, 11, 273-293. [CrossRef] [PubMed]

49. Hayward, J.A.; Rajendran, E.; Zwahlen, S.M.; Faou, P.; van Dooren, G.G. Divergent features of the coenzyme Q:cytochrome c oxidoreductase complex in Toxoplasma gondii parasites. PLoS Pathog. 2021, 17, e1009211. [CrossRef] [PubMed]

50. Iltzsch, M.H. Pyrimidine salvage pathways in Toxoplasma gondii. J. Eukaryot. Microbiol. 1993, 40, 24-28. [CrossRef]

51. Fox, B.A.; Bzik, D.J. De novo pyrimidine biosynthesis is required for virulence of Toxoplasma gondii. Nature 2002, 415, 926-929. [CrossRef]

52. Kather, B.; Stingl, K.; van der Rest, M.E.; Altendorf, K.; Molenaar, D. Another unusual type of citric acid cycle enzyme in Helicobacter pylori: The malate:quinone oxidoreductase. J. Bacteriol. 2000, 182, 3204-3209. [CrossRef]

53. Bulusu, V.; Jayaraman, V.; Balaram, H. Metabolic fate of fumarate, a side product of the purine salvage pathway in the intraerythrocytic stages of Plasmodium falciparum. J. Biol. Chem. 2011, 286, 9236-9245. [CrossRef]

54. Ke, H.; Lewis, I.A.; Morrisey, J.M.; McLean, K.J.; Ganesan, S.M.; Painter, H.J.; Mather, M.W.; Jacobs-Lorena, M.; Llinas, M.; Vaidya, A.B. Genetic investigation of tricarboxylic acid metabolism during the Plasmodium falciparum life cycle. Cell Rep. 2015, 11, 164-174. [CrossRef] [PubMed]

55. Ke, H.; Morrisey, J.M.; Ganesan, S.M.; Painter, H.J.; Mather, M.W.; Vaidya, A.B. Variation among Plasmodium falciparum strains in their reliance on mitochondrial electron transport chain function. Eukaryot. Cell 2011, 10, 1053-1061. [CrossRef] 
56. Painter, H.J.; Morrisey, J.M.; Mather, M.W.; Vaidya, A.B. Specific role of mitochondrial electron transport in blood-stage Plasmodium falciparum. Nature 2007, 446, 88-91. [CrossRef] [PubMed]

57. Mogi, T.; Murase, Y.; Mori, M.; Shiomi, K.; Omura, S.; Paranagama, M.P.; Kita, K. Polymyxin B identified as an inhibitor of alternative NADH dehydrogenase and malate: Quinone oxidoreductase from the Gram-positive bacterium Mycobacterium smegmatis. J. Biochem. 2009, 146, 491-499. [CrossRef] [PubMed]

58. Molenaar, D.; van der Rest, M.E.; Petrović, S. Biochemical and genetic characterization of the membrane-associated malate dehydrogenase (acceptor) from Corynebacterium glutamicum. Eur. J. Biochem. 1998, 254, 395-403. [CrossRef] [PubMed]

59. Molenaar, D.; van der Rest, M.E.; Drysch, A.; Yücel, R. Functions of the membrane-associated and cytoplasmic malate dehydrogenases in the citric acid cycle of Corynebacterium glutamicum. J. Bacteriol. 2000, 182, 6884. [CrossRef]

60. van der Rest, M.E.; Frank, C.; Molenaar, D. Functions of the membrane-associated and cytoplasmic malate dehydrogenases in the citric acid cycle of Escherichia coli. J. Bacteriol. 2000, 182, 6892-6899. [CrossRef]

61. Niikura, M.; Komatsuya, K.; Inoue, S.-I.; Matsuda, R.; Asahi, H.; Inaoka, D.K.; Kita, K.; Kobayashi, F. Suppression of experimental cerebral malaria by disruption of malate:quinone oxidoreductase. Malar. J. 2017, 16, 247. [CrossRef] [PubMed]

62. Wang, X.; Miyazaki, Y.; Inaoka, D.K.; Hartuti, E.D.; Watanabe, Y.-I.; Shiba, T.; Harada, S.; Saimoto, H.; Burrows, J.N.; Benito, F.J.G.; et al. Identification of Plasmodium falciparum mitochondrial malate: Quinone oxidoreductase inhibitors from the pathogen Box. Genes 2019, 10, 471. [CrossRef]

63. Araki, Y.; Awakawa, T.; Matsuzaki, M.; Cho, R.; Matsuda, Y.; Hoshino, S.; Shinohara, Y.; Yamamoto, M.; Kido, Y.; Inaoka, D.K.; et al. Complete biosynthetic pathways of ascofuranone and ascochlorin in Acremonium egyptiacum. Proc Natl. Acad. Sci. USA 2019, 116, 8269. [CrossRef]

64. Hijikawa, Y.; Matsuzaki, M.; Suzuki, S.; Inaoka, D.K.; Tatsumi, R.; Kido, Y.; Kita, K. Re-identification of the ascofuranoneproducing fungus Ascochyta viciae as Acremonium sclerotigenum. J. Antibiot. 2017, 70, 304-307. [CrossRef] [PubMed]

65. Borisov, V.B.; Gennis, R.B.; Hemp, J.; Verkhovsky, M.I. The cytochrome $b d$ respiratory oxygen reductases. Biochim. Biophys. Acta Bioenerg. 2011, 1807, 1398-1413. [CrossRef]

66. Forte, E.; Borisov, V.B.; Falabella, M.; Colaço, H.G.; Tinajero-Trejo, M.; Poole, R.K.; Vicente, J.B.; Sarti, P.; Giuffrè, A. The terminal oxidase cytochrome $b d$ promotes sulfide-resistant bacterial respiration and growth. Sci. Rep. 2016, 6, 23788. [CrossRef]

67. Kita, K.; Konishi, K.; Anraku, Y. Terminal oxidases of Escherichia coli aerobic respiratory chain. II. Purification and properties of cytochrome $b_{558^{-}} d$ complex from cells grown with limited oxygen and evidence of branched electron-carrying systems. J. Biol. Chem. 1984, 259, 3375-3381. [CrossRef]

68. Nihei, C.; Fukai, Y.; Kawai, K.; Osanai, A.; Yabu, Y.; Suzuki, T.; Ohta, N.; Minagawa, N.; Nagai, K.; Kita, K. Purification of active recombinant trypanosome alternative oxidase. FEBS Lett. 2003, 538, 35-40. [CrossRef]

69. Ohshima, T.; Tanaka, S. Dye-linked L-malate dehydrogenase from thermophilic Bacillus species DSM 465. Purification and characterization. Eur. J. Biochem. 1993, 214, 37-42. [CrossRef]

70. Shinagawa, E.; Fujishima, T.; Moonmangmee, D.; Theeragool, G.; Toyama, H.; Matsushita, K.; Adachi, O. Purification and characterization of membrane-bound Malate dehydrogenase from Acetobacter sp. SKU 14. Biosci. Biotechnol. Biochem. 2002, 66, 298-306. [CrossRef]

71. Oh, Y.-R.; Jang, Y.-A.; Hong, S.H.; Eom, G.T. Purification and characterization of a malate:quinone oxidoreductase from Pseudomonas taetrolens capable of producing valuable lactobionic acid. J. Agric. Food Chem. 2020, 68, 13770-13778. [CrossRef] [PubMed]

72. Kabashima, Y.; Sone, N.; Kusumoto, T.; Sakamoto, J. Purification and characterization of malate:quinone oxidoreductase from thermophilic Bacillus sp. PS3. J. Bioenerg. Biomembr. 2013, 45, 131-136. [CrossRef]

73. Chrétien, D.; Bénit, P.; Ha, H.-H.; Keipert, S.; El-Khoury, R.; Chang, Y.-T.; Jastroch, M.; Jacobs, H.T.; Rustin, P.; Rak, M. Mitochondria are physiologically maintained at close to $50{ }^{\circ} \mathrm{C}$. PLoS Biol. 2018, 16, e2003992. [CrossRef]

74. Macherel, D.; Haraux, F.; Guillou, H.; Bourgeois, O. The conundrum of hot mitochondria. Biochim. Biophys. Acta Bioenerg. 2021, 1862, 148348. [CrossRef]

75. Lindsay, D.S.; Mitschler, R.R.; Toivio-Kinnucan, M.A.; Upton, S.J.; Dubey, J.P.; Blagburn, B.L. Association of host cell mitochondria with developing Toxoplasma gondii tissue cysts. Am. J. Vet. Res. 1993, 54, 1663-1667.

76. Nelson, M.M.; Jones, A.R.; Carmen, J.C.; Sinai, A.P.; Burchmore, R.; Wastling, J.M. Modulation of the host cell proteome by the intracellular apicomplexan parasite Toxoplasma gondii. Infect. Immun. 2008, 76, 828. [CrossRef]

77. Pernas, L.; Adomako-Ankomah, Y.; Shastri, A.J.; Ewald, S.E.; Treeck, M.; Boyle, J.P.; Boothroyd, J.C. Toxoplasma effector MAF1 mediates recruitment of host mitochondria and impacts the host response. PLoS Biol. 2014, 12, e1001845. [CrossRef] [PubMed]

78. Sinai, A.P.; Webster, P.; Joiner, K.A. Association of host cell endoplasmic reticulum and mitochondria with the Toxoplasma gondii parasitophorous vacuole membrane: A high affinity interaction. J. Cell Sci. 1997, 110, 2117-2128. [CrossRef] [PubMed]

79. Lahouel, M.; Zini, R.; Zellagui, A.; Rhouati, S.; Carrupt, P.-A.; Morin, D. Ferulenol specifically inhibits succinate ubiquinone reductase at the level of the ubiquinone cycle. Biochem. Biophys. Res. Commun. 2007, 355, 252-257. [CrossRef] [PubMed]

80. Appendino, G.; Mercalli, E.; Fuzzati, N.; Arnoldi, L.; Stavri, M.; Gibbons, S.; Ballero, M.; Maxia, A. Antimycobacterial coumarins from the sardinian giant fennel (Ferula communis). J. Nat. Prod. 2004, 67, 2108-2110. [CrossRef]

81. Bell, R.G.; Sadowski, J.A.; Matschiner, J.T. Mechanism of action of warfarin. Warfarin and metabolism of vitamin $\mathrm{K}_{1}$. Biochemistry 1972, 11, 1959-1961. [CrossRef] [PubMed] 
82. Fasco, M.J.; Principe, L.M.; Walsh, W.A.; Friedman, P.A. Warfarin inhibition of vitamin K 2,3-epoxide reductase in rat liver microsomes. Biochemistry 1983, 22, 5655-5660. [CrossRef]

83. Sadler, J.E. K is for koagulation. Nature 2004, 427, 493-494. [CrossRef]

84. Bocca, C.; Gabriel, L.; Bozzo, F.; Miglietta, A. Microtubule-interacting activity and cytotoxicity of the prenylated coumarin ferulenol. Planta Med. 2002, 68, 1135-1137. [CrossRef] [PubMed]

85. Gebauer, M. Synthesis and structure-activity relationships of novel warfarin derivatives. Bioorganic Med. Chem. 2007, 15, 2414-2420. [CrossRef] [PubMed]

86. Li, W.; Schulman, S.; Dutton, R.J.; Boyd, D.; Beckwith, J.; Rapoport, T.A. Structure of a bacterial homologue of vitamin K epoxide reductase. Nature 2010, 463, 507-512. [CrossRef] [PubMed]

87. Huang, L.-s.; Luemmen, P.; Berry, E. Crystallographic investigation of the ubiquinone binding site of respiratory Complex II and its inhibitors. Biochim. Biophys. Acta Proteins Proteom. 2021, 3, 140679. [CrossRef] [PubMed]

88. Sato, D.; Hartuti, E.D.; Inaoka, D.K.; Sakura, T.; Amalia, E.; Nagahama, M.; Yoshioka, Y.; Tsuji, N.; Nozaki, T.; Kita, K.; et al. Structural and biochemical features of Eimeria tenella dihydroorotate dehydrogenase, a potential drug target. Genes 2020, 11, 12. [CrossRef]

89. Balogun, E.O.; Inaoka, D.K.; Shiba, T.; Tsuge, C.; May, B.; Sato, T.; Kido, Y.; Nara, T.; Aoki, T.; Honma, T.; et al. Discovery of trypanocidal coumarins with dual inhibition of both the glycerol kinase and alternative oxidase of Trypanosoma brucei brucei. FASEB J. 2019, 33, 13002-13013. [CrossRef]

90. Shiba, T.; Inaoka, D.K.; Takahashi, G.; Tsuge, C.; Kido, Y.; Young, L.; Ueda, S.; Balogun, E.O.; Nara, T.; Honma, T.; et al. Insights into the ubiquinol/dioxygen binding and proton relay pathways of the alternative oxidase. Biochim Biophys. Acta Bioenerg. 2019, 1860, 375-382. [CrossRef]

91. Holdgate, G.A.; Meek, T.D.; Grimley, R.L. Mechanistic enzymology in drug discovery: A fresh perspective. Nat. Rev. Drug Dis. 2018, 17, 115-132. [CrossRef]

92. Ebiloma, G.U.; Ayuga, T.D.; Balogun, E.O.; Gil, L.A.; Donachie, A.; Kaiser, M.; Herraiz, T.; Inaoka, D.K.; Shiba, T.; Harada, S.; et al. Inhibition of trypanosome alternative oxidase without its N-terminal mitochondrial targeting signal ( $\triangle \mathrm{MTS}-\mathrm{TAO})$ by cationic and non-cationic 4-hydroxybenzoate and 4-alkoxybenzaldehyde derivatives active against T. brucei and T. Congolense. Eur. J. Med. Chem. 2018, 150, 385-402. [CrossRef] [PubMed]

93. Laemmli, U.K. Cleavage of structural proteins during the assembly of the head of bacteriophage T4. Nature 1970, 227, 680-685. [CrossRef] [PubMed]

94. Inaoka, D.K.; Iida, M.; Tabuchi, T.; Honma, T.; Lee, N.; Hashimoto, S.; Matsuoka, S.; Kuranaga, T.; Sato, K.; Shiba, T.; et al. The open form inducer approach for structure-based drug design. PLoS ONE 2016, 11, e0167078. [CrossRef] [PubMed] 